\title{
PROBLEMS OF STRATEGIC MANAGEMENT IN RURAL TOURISM
}

\section{STEFAN BOSIACKI, BERNADETA HOŁDERNA-MIELCAREK}

University School of Physical Education in Poznan, POLAND

e-mail: holderna-mielcarek@awf.poznan.pl

RECEIVED
ACCEPTED
JEL
CLASSIFICATION

KEYWORDS

ABSTRACT
12 May 2017

12 August 2017

018, Z32

strategic management, rural tourism, Wielkopolska

This article focuses on the concept of strategic management in the rural tourism sector. It presents the assumptions and methodology of this concept in the formulation of tourism development strategies in rural areas. It shows a relational and network approach in the development of the tourism product against the background of building distinctive regional competences. An example of practical use of the concept of strategic management in the development of rural tourism in the Wielkopolska voivodship is presented.

\section{Introduction}

The program for tourism development up to 2020 , developed by the Ministry of Sport and Tourism, emphasizes that the key strategic objective for this sector will be to strengthen the development of competitive and innovative tourism by supporting businesses, organizations and institutions as well as tourism sector initiatives, with respect to the principles of sustainable development. (Program, 2015, p. 36). The numerous operational objectives include those that relate to the creation and development of regional and local tourism products based on the existing, attractive tourist assets and resources of individual areas. Rural tourism can be undoubtedly such regional and local tourism products, providing that they will be created and developed in the modern, innovative manner and, more importantly, they will constitute an element of the general system of strategic management in the particular area. In today's practice of strategic management of the tourism sector, the most important is its perception as an important element of the socio-economic development of the region (area). 
In other words, tourism is developing in a specific area, in a specific space, thus it is important to think about it in the context of an area-based tourism product. It consists of: attractions and destination environment, infrastructure and destination services, availability of destination, image and perception of destination (Gardzińska, 2009, p. 48). While offering tourists a holiday within the framework of rural tourism, various services are provided by businesses and individuals, on the basis of the existing tourism and para-tourism development, cultural and historical heritage, hospitality and goodwill of the local inhabitants, and even the ones related to the image of the area and the events that will only occur during the tourist's stay (Kaczmarek, Stasiak, Włodarczyk, 2005, p. 54). We should also agree with Lane's statement that contemporary rural tourism is an interesting market for many specialized forms of tourism. It covers not only tourism in agricultural holdings, but also trips connected with particular interests: nature holidays and ecotourism, walking, climbing and riding holidays, adventure, sport and health tourism, hunting and angling, educational tourism, arts and heritage tourism, and in some areas ethnic tourism (Lane, 1994, cited in Page, Gatz, 1997, p. 8). So it can be stated that also in rural tourism we deal with a product being an aggregate of diverse goods and services, which cater to different needs and expectations of tourists. However, in order to satisfy these needs and expectations, the cooperation between the entities and institutions working for tourists in the area (in the locality) is necessary, and the objectives previously established in the regional or local development strategy have to be implemented. ${ }^{1}$

The aim of this paper is to present the possibility of using a relational and network approach in strategic management on the regional basis, supporting regional competence in tourism product development.

\section{Relational and network approach to strategic management in rupal tourism by region}

The development of the concept of strategic management and the assumptions for strategy formulation, present diverse approaches that support the organization's pursuit of market objectives. The literature of the subject demonstrates the exploration of various approaches of strategic management schools as well as their relevant characteristics and relationships including planning, resource, relational and network concepts (i.a. Zakrzewska-Bielawska, 2014, pp. 9-29; Gołębiewski, 2001, pp. 17-37). This paper focuses on the presentation of the assumptions of the relational and network approach in strategic management in rural tourism on the regional level, and the concept of regional network tourism product. The considerations simultaneously take into account the concept, process and attributes of strategic management. In this regard, it should also be noted that strategic management in the tourism sector on the regional basis is an interdisciplinary and complex process. As revealed, it concerns many subjects engaged in the development of tourism, representing different socio-economic and public spheres. Individual entities involved in the organization and operation of tourism formulate their own development strategies and devise appropriate functional programs. However, they have limited resources and access to the other ones while creating the shared value for the tourist. On the other hand, in a tourist's perception, the tourism offer of the area is identified as a comprehensive product having the nature of complementary goods and services, providing some specific - expected benefits. It can

\footnotetext{
${ }^{1}$ According to OECD list of contrasting features between urban/resort tourism and rural tourism could include the following: Much open space, Settlements under 10,000, Sparsely populated, Natural environment, Many outdoor activities, Infrastructure - weak, Strong individual activity base, Small establishments, Locally owned businesses, Much part-time involvement in tourism, Some farm/ forestry involvement, Tourism supports other interests, Workers often live, close to workplace, Often influenced, by seasonal factors, Few guests, Guest relationships personal, Amateur management, Local in atmosphere, Many older buildings, Conservation/limits to growth ethic, Specialist appeal, Niche marketing (OECD, 1994, pp. 14-15).
} 
therefore be concluded that what is important in shaping the strategy for tourism development in rural areas is the approach of mutual complementarity and common use of resources, increasing the value provided and improving the efficiency of the entities belonging to the network. As a result they build new competences of higher productivity than their competitors. Diversified tourist needs and motives, as factors driving travel to rural areas, determine the creation of various tourism products. Decisions concerning the choice of scope and type of action, oriented on target market segments, are related to the definition of strategic business units. According to Levitt, defining a domain of action in terms of market rather than a product, makes it easier to adapt to changes in the environment, modify products and develop new ones (cf. Kotler, 1999, p. 63). In this context, identification of the needs of tourists allows for the development of goods and services which, in turn, by complementing and integrating particular functions, domains of action and coordination processes can support the achievement of synergy effects. In rural tourism, activities may focus on one type of activity or several connected types which can be planned separately.

Relational and network approaches in strategic management (a relationship-oriented strategy in the tourism value chain and a network-oriented strategy for actors involved in the development of tourism in the region) are based on the assumption that resources and modes of interaction can become outstanding cross-regional competencies through co-operation or/and the integration of actors and coordination of activities. That said, it is important to bear in mind the possibility of developing various concepts of cooperation (relations), characterized by M. Ratajczak-Mrozek, such as: business networks, network organizations, clusters. As the cited author states, the essence of business networks is the relation, and formal or informal type of cooperation is a secondary issue. Their attributes are continuous interaction, interdependence of resources, entities and activities and infinity of connections, lack of clear boundaries and structure. On the other hand, network organizations are characterized by a complex organizational structure resulting from the strategic cooperation of partners (strategic alliances), including integrated, federated, contractual, and direct relations networks. The clusters' distinctive features are: the geographical proximity of cluster participants allowing for the use of the same resources and of common industry level, and frequently the formal structure and formal institution or coordinating institution (Ratajczak-Mrozek, 2009, pp. 79-89). W. Rudny points to the important aspects related to the design and operation of business networks, including: 1) pooling of resources of network participants (technical resources: products and infrastructure, organizational resources: organizational units and inter-organizational relationships) in order to create a new value; 2) analysis of the combination of resources and a formal description of the relationships between the resources, pooling of resources or a coordination mechanism; 3) forms of coordination for building relationships with other entities (lack of cooperation, cooperation or takeover), choice between the development of the resource base independently, with no external partner, or using other actors (Rudny, 2014, pp. 26-28). We should also agree with the benefits for rural tourism development resulting from the attributes of inter-organizational networks as presented by J. Matysiewicz, that concern searching for market opportunities in the scope of creating new market offers which are more integrated and more attractive in terms of prices, discovering new markets, better satisfaction of consumer needs, and are characterized by the effectiveness of a jointly implemented strategy which is higher than the effectiveness provided by individual strategies (Matysiewicz, 2013, p. 65). According to the Polish Tourist Organization, a network tourism product is a "ready-to-sell packaged offer based on a dispersed structure of entities, attractions, places, service points, objects, functioning as one coherent concept with a common, leading strong discriminant (brand) of a product (POT, 2008). In this context, the implementation of the development strategy for the network tourism product is related to the identification of relations between particular network entities which would contribute to creating the value for tourists and establishing the scope of tasks and mechanisms for coordinating the work of network actors 
and the monitoring system of the activities being undertaken, as well as the possibility of introducing changes. The model approach to the network tourism product is presented by M. Kachniewska, who distinguishes its three important components. Knowledge as the first component of the concept, which deals with the understanding of the essence and the process of creating a network tourism product. The second component is the subject-oriented approach and the division of roles between network participants. The third component is defining of the territorial coverage, which is specified by the substantive scope of the network product concept (Kachniewska, 2014/2015, pp. 25-44).

\section{Strategic management based on the Strategy for the development of tourism of the Wiellopolskia Voivodship up to 2020}

An example of the use of the concept of strategic management in the development of rural tourism is the study concerning a tourism development strategy in the Wielkopolska voivodship. The approach adopted by the authors of the Strategy includes selected components of strategic planning, implementation and control of undertaken actions. The division of tasks in the development of tourism assigned to the voivodship local government and other entities, refers to the theoretical approach of the strategic management concept at the regional level. The tasks of the voivodeship local government in the sector of development of tourism products listed by the authors of the Strategy, not only in rural areas, consist mainly in indicating directions of their development, creating favorable conditions for their implementation, supporting initiatives consistent with the directions, were defined as organizational, training and marketing support. On the other hand, construction of tourism products was attributed to other entities. A strategic goal was also defined, resulting primarily from the analysis of the rural resources of the voivodship, which was defined as the "Development of rural tourism products", as well as the operational objectives oriented towards the increase in the attractiveness of rural tourism products, enhancing the quality of services provided by rural tourism facilities, and intensifying the informative and promotional activities. Measures to achieve the aforementioned objectives have also been developed, including among others supporting the construction and extension of rural tourism facilities, in particular the adaptation of historic buildings and sites for tourism purposes (e.g. memorial exhibition rooms, open air museums), specialized and competitive products emphasizing authenticity, locality and culture (local traditions and customs) including the so-called "thematic villages", supporting events and happenings promoting local culture - traditions and customs of Wielkopolska countryside and regional cuisine, supporting projects related to improving the aesthetics of Wielkopolska countryside and rural tourism facilities, investing in appropriate equipment and appearance of the facilities and their surroundings, promoting good practice, increasing the competences and awareness of the personnel that influence the shaping of rural tourism products, intensifying promotional activities using traditional and modern forms of promotion, and the inclusion of rural tourism facilities as an integral part of the offer of business, active, cultural and natural tourism products. Quantitative measures of achievement of the strategic goal have been defined: number of agro-tourism lodging establishments, number of training courses/workshops for the administrators of rural tourism facilities and local governments, the number of organized or supported competitions and projects promoting rural tourism. The sources of financing for the planned activities were also indicated, including own funds of the local governments, the funds of the Rural Development Program for the years 2014-2020 (sub-measure 7.6), own financial resources of Wielkopolska Tourist Organization, private funds and funds from other entities involved in the achievement of the strategic goal (Strategy for the development of tourism in Wielkopolska Voivodship until the year 2020, 2016).

The development of innovative rural tourism products in Wielkopolska, based on various forms of cooperation, can contribute to more efficient and effective satisfaction of the needs of tourists. Table 1 gives the characteristics 
of four segments of rural tourism relating to the observed consumer and tourism trends, which appear to be an interesting option for the development of network tourism products in Wielkopolska.

Table 1. Chosen segments of rural tourism

Tourism consumption oriented towards the pro-ecological features of the tourist offer

Purchase decisions can be motivated by: 1) experiences connected with contact with nature, among others. aesthetic experiences, e.g. admiring and photographing nature, "magical” e.g. observation of unique natural phenomena (e.g. plants flowering, birds arrivals), educational, e.g. cognitive wandering related to the topic of ecosystems, workshops and ecological actions; 2) pro-ecological criteria of the tourist offer concerning, inter alia, preserving the natural landscape and its aesthetics, proper location of tourism and recreation facilities and their capacity, introduction of proenvironmental infrastructure solutions (e.g. renewable energy sources, water and energy-saving equipment, pro-environmental transport solutions, pro-environmental waste management), participation in environmental protection projects, development of ecological crops and healthy food, promotion of environmentally friendly forms of tourism and recreation in the region. Tourism needs and behaviors fit in with the trend of conscious consumption and lifestyle - slow life, slow travel ${ }^{*}$

Consumption of tourism products oriented on physical activity

Purchasing decisions can be motivated by the experiences of taking up various forms of physical activity in rural areas, including among others: taking action for health, well-being, doing something for the body and its shape (e.g. fitness/wellness, jogging, aerobics, yoga), the sense of possibility of achieving something together, meeting friends and getting to know nice people, also through passive participation in sports events (e.g. racing, hiking/ biking, team games and activities), experiencing some special emotion, „triggering adrenaline”, checking one's own physical capacity/ fitness along with prestige and recognition (e.g. extreme sports). Needs and behavior are associated with an active lifestyle ***

Tourism consumption motivated by the search for contact with culture, new ideas and relations in tourism

Purchasing decisions motivated by the need, among others, of discovering own identity, searching for contacts with cultures, visiting family places, experiencing the authenticity such as participation in local events and behaviors from the "backstage" area, avoiding the beaten track, popular attractions, crowds of tourists, feeling of being special and unique, co-participating in the processes of making souvenirs, behavioral characteristics are coincident with Cohen's tourist types: „seeker of experiments”, „existential tourist **. The second segment is Cohen's type of recreational tourist, motivated by the desire to participate in the staging of a tourism product, e.g. historical reconstruction, interactive forms of interpretation of cultural heritage, guesting, geocaching, theme parks and entertainment parks ${ }^{* * *}$

Demonstrative consumption motivated by prestige and as expression of lifestyle

Purchasing decisions concern two segments of consumption of luxury tourism services offered in rural areas: 1) strong motivation according to T. Verblen with respect to goods used to signal wealth, power or social status; 2 ) in other segments, apart from the aspect of conspicuous consumption, conspicuous consumption the motivation is a demonstration of a unique lifestyle, and the acquisition of products shifts towards experience and a symbolic image. Consumers no longer want to ostentatiously emphasize their position (e.g. through extravagance and large expenses), but they do it through more subtle behavior in the market ${ }^{* * * *}$

Source: developed on the basis of: *Zalaga (2013), **Skalska, Markiewicz, Pędzierski (2016), ${ }^{* * * Z a n g e r ~(2005), ~}{ }^{* * *}$ F. Bylok 2013.

Creation of network rural tourism products in Wielkopolska includes: 1) tourism product concept, e.g. nature based products, recreational activities, local culture, customs, regional cuisine; 2) identification of possessed key competences (material and non-material resources, including product quality, brand, distribution network: suppliers, partners) and their function in creating the value for tourists; 3) following the definition of their combinations, forms of relationship between actors and ways of coordinating actions, i.e. links between network participants and, among others with the competitors, tourism organizations and scientific and research centers, territorial self-government units (horizontal networks), relations within the tourism supply chain, e.g. based on the cooperation of co-organizers of cultural/sports events, hotel establishments, regional cuisine establishments, sports and active recreation facilities, tourist guides (vertical networks). The factors affecting the abovementioned aspects of the network's functioning, concerning the competence of cooperative entities, the structure of the local tourism economy, which constitute an important area of further research, should be taken into consideration. The research into the efficiency of networks and participating entities, as well as the benefits to local communities and the environment are also of great importance. 


\section{Conclusion}

Rural tourism is and will be a significant product on the Polish tourism market, a product with good future development prospects. This, however, depends on dealing with this form of tourism as part of an overall strategy for the development of tourism in a given area (at national, regional, commune or locality level). Without the use of strategic management methods and instruments, it will be difficult to make rural tourism a branded product on the domestic market, and even more so on the competitive international tourism services market.

\section{References}

Bylok, F. (2013). Konsumpcja na pokaz jako cecha rynku konsumenckiego. Scientific Writing University of Szczecin, 777, Problems of Management, Finance and Marketing, 32, 28-29.

Gardzińska, A. (2009). Specyfika obszarowego produktu turystycznego. In: B. Meyer, D. Milewski (eds.), Strategie rozwoju turystyki w regionie (pp. 47-54). Warszawa: Wydawnictwo Naukowe PWN.

Gołębiewski, T. (2001). Zarządzanie strategiczne. Planowanie i kontrola. Warszawa: Difin.

Kachniewska, M.(2014/2015). Model tworzenia sieciowego produktu turystycznego. Warszawa: Mazovian Regional Tourist Organization. Kaczmarek, J., Stasiak, A., Włodardczyk, B. (2005). Produkt turystyczny, pomysł, organizacja, zarządzanie. Warsaw: PWE Publishing Hause. Kotler, Ph. (1999). Marketing, Analiza, planowanie, wdrażanie i kontrola. Warsaw, FELBERG SJA Publishing House.

Matysiewicz, J. (2013). Budowanie sieci międzyorganizacyjnych jako podstawa kreowania wartości w marketingu usług profesjonalnych. Domestic Trade. Market. Company. Consumption. Marketing. Marketing means of creating value for customers 2, May-June. Warsaw: Institute for Market, Consumption and Business Cycles Research, 64-71.

Page, S.J., Gezt, D. (1997). The Business of Rural Tourism: International Perspectives, International Thomson Business Press.

Polish Tourist Organization. Retrieved from: https://www.pot.gov.pl/fundusze/slownik/sieciowy-produkt-turystyczny (5.04.2017).

Program rozwoju turystyki do 2020 roku. Warsaw: Ministry of Sport and Tourism.

Ratajczak-Mrozek, M. (2009). Sieci biznesowe na tle innych koncepcji kooperacji przedsiębiorstw. National Economy, 7-8. 79-91.

Rudny, W. (2014). Zasoby sieciowe a strategia przedsiębiorstwa. Economic Studies, 202. Scientific Writing University of Economy in Katowice, 23-33.

Skalska, T., Markiewicz, E., Pędzierski, M. (2016), Konsumpcja kolaboratywna w obszarze turystyki. Próba prezentacji stanu zjawiska na rynku polskim. Folia Turistica, 41, 165-190.

Strategia rozwoju turystyki w województwie wielkopolskim do 2020 roku. Administration of Wielkopolska Voivodship, 2016, App. 1 to Resolution XVIII 481/16 of the Local Parliament of Wielkopolskie Voivodship of 25.04.2016, 47-50.

Tourism Strategies and Rural Development, Organisation for Economic Co-operation and Development, 49 (94). Paris: OECD/GD, 14-15.

Zakrzewska-Bielawska, A. (2014). Ewolucja szkół strategii: przegląd głównych podejść i koncepcji. In R. Krupski (ed.), Strategic Management. Development of concepts and mathods (pp. 9-29). Scientific Papers of Walbrzych Higher School of Management and Enterprise 27, Wałbrzych.

Zalaga, T. (2013). Nowe trendy i makrotrendy w zachowaniach konsumenckich gospodarstw domowych w XXI wieku. Consumption and Development, Institute for Market, Consumption and Business Cycles Research, 2 (5), 12-18.

Zanger, C. (2005). Das Eventpotenzial von Sprtarten. Handbuch Sportmanagement. Schorndorf: Ch. Breuer, A. Thiel, Hofmann Verlag.

Cite this article aS: Bosiacki, S., Hołderna-Mielcarek, B. (2017). The influence of regional culinary traditions on the attractiveness of agrotourism offer. European Journal of Service Management, 4 (24), 17-22. DOI: 1.18276/ejsm.2017.24-03. 